\title{
INTEGRITAS DAI DALAM MENENTUKAN KEBERHASILAN DAKWAH
}

Rodiyah*

Abstrak

Tulisan ini menjelaskan tentang peran dai dalam kegiatan dakwah, integritas kepribadian dai menjadi salah satu faktor yang akan mendukung keberhasilan dakwah dai, penulis mencoba untuk menjelaskan tentang posisi dai dalam kegiatan dakwah dengan merujuk pendapat para ahli di bidang dakwah, setelah itu penulis mendeskripsikan tentang penting integritas dai sebagai salah satu unsur penting dalam menentukan keberhasilan dakwah.

Kata Kunci: Integritas, dai, keberhasilan dakwah

\section{Pendahuluan}

Masyarakat merupakan mitra sekaligus sasaran dalam proses kegiatan dakwah yang memiliki harapan besar kepada dai sebagai pelaksana dakwah, walaupun tidak semua harapan masyarakat tersebut ada dalam diri dai, Namun kelemahan dan kekurangan yang dimiliki dai sebagai manusia biasa bukanlah menjadi alasan bagi dai untuk terus introfeksi diri untuk menjadi lebih baik lagi. Hal itu dikarenakan dai haruslah menyadari bahwa dia adalah teladan bagi umat, yang akan menjdi salah satu sumber rujukan umat dalam menyelesaikan persoalan agama dan persoalan sosial, karena Integritas kepribadian merupakan faktor penting yang dapat mendukung keberhasilan dakwah.

\section{A. Urgensi Dakwah Dalam Islam}

Dakwah merupakan kewajiban syar'i bagi setiap individu Muslim sekaligus merupakan kebutuhan primer manusia secara menyeluruh. Hal itu karena, kebutuhan utama manusia pada dasarnya adalah ingin mengetahui tentang dirinya, pencipta segala yang ada dan kemana manusi pergi setelah ajal tiba. Sedangkan yang dapat menjawab semua itu adalah agama yang benar, dan kebenaran tersebut sampai kepada manusia melalui dakwah.

Dengan demikian, dakwah dalam kehidupan masyarakat memiliki kedudukan yang sangat penting, terutama dalam upaya merekonstruksi masyarakat yang masih mengandung unsur jahiliyah menjadi masyarakat yang islami. Maka dari itu, dakwah tidak hanya sekedar menyampaikan ajaran Islam, tapi lebih dari itu karena dakwah juga sebagai 
upaya mengaktualisasikan nilai-nilai Islam, serta sebagai upaya penerapan Islam sebagai rahmatan lil'alamin, yang lebih menekankan pada aktualisasi nilainilai Islam secara universal. ${ }^{1}$ Dakwah juga merupakan usaha untuk merubah masyarakat dari suatu situasi kepada situasi yang lebih baik, sesuai dengan tuntunan Allah SWT yang disertai dengan kesadaran dan tanggung jawab kepada diri sendiri, orang lain, dan kepada Allah SWT. ${ }^{2}$

\section{B. Peran Dai dalam Dakwah Islam}

Kehadiran seorang dai menjadi penting untuk mengkomunikasikan ajaran Islam tersebut kepada masyarakat. Melalui pesan-pesan dakwah yang disampaikan oleh dai esensi ajaran Islam akan sampai kepada masyarakat, sehingga masyarakat bisa membedakan antara yang haq dengan yang bathil, sesuai dengan tuntunan Islam. Dakwah merupakanUsaha untuk mengajak meyakni dan mengamalkan aqidah syariat Islam dengan terlebih dahulu telah diyakini dan diamalkan oleh dai. ${ }^{3}$

Hal itu dikarenakan tugas amar ma'ruf nahi munkar sangat dibutuhkan pada saat ini, Allah Swt juga beri ganjar yang besar bagi orang yang melaksanakannya dengan baik, maka kepentingan dunia dan akhiratnya akan dicukupkan oleh Allah Swt, tugas suci ini dapat dilaksanakan dengan cara apa saja yang disanggupi baik dengan ucapkan, tulisan dan dengan berbagai macam majelis pengajian yang sengaja diadakan. ${ }^{4}$

Mengingat hal tersebut, maka kegiatan dakwah memerlukan seorang aktifis yang profesional yang bergerak di bidang tersebut. Hal tersebut juga dikarenakan tugas dakwah merupakan tugas yang berat karena sasaran dakwah adalah mahluk hidup dinamis kreatif yang mampu mengevaluasi tindakan sendiri maupun tindakan orang lain.

Gambaran tersebut menunjukkan bahwa para dai yang berperan sebagai aktivis dakwah memerlukan persiapan yang matang. Selain membekali diri dengan berbagai ilmu pengetahuan dan ketrampilan yang menunjang keberhasilan dakwah, seorang dai idealnya juga memiliki hubungan yang dekat dengan Allah dan berakhlak mulia, karena setiap tingkah laku dai menjadi cerminan dan tolak ukur bagi masyarakat. Untuk kepentingan itu para dai diharapkan bisa menjadikan Rasulullah sebagai teladan. Sesuai dengan tuntunan Allah dalm surat Al-Ahzab ayat 21

yang Artinya:"Sesungguhnya telah ada pada (diri ) Rasulullah itu terdapat suri teladan uyang baik bagimu (yaitu bagi orang yang mengharap (rahmat) 
Allah (kedatangan) hari kiamat dan dia banyak menyebut Allah" (Q.S. AlAhzab" 21). ${ }^{5}$

Ayat diatas menerangkan bahwa Rasulullah Saw merupakan contoh teladan utama bagi setiap pribadi Muslim, lebih-lebih bagi para aktivis dakwah yang lebih dikenal dengan sebutan dai. Hal itu dikarenakan dai pada dasarnya adalah penerus perjuangan Rasulullah untuk menegakkan ajaran Islam di tengahtengah masyarakat.

\section{Integritas Sorang Da'i}

Kedudukan dai sebagai pembawa misi mulia dari Allah dan penerus risalah Rasulullah, sudah seyogyanya seorang dai memiliki hubungan dekat dengan Allah dan menjadikan Rasulullah Saw sebagai teladan, sebagaimana yang telah diungkapkan diatas. Mengingat dakwah pada hakikatnya tidak hanya sekedar menyampaikan ajaran Islam atau proses penyebaran ajaran Islam atau sosialisasi nilai kebenaran yang dikenal juga dengan dimensi kerisalahan tapi dakwah juga mencakup pengaplikasian nilai-nilai Isalm atau nilai kebenaran yang dikenal juga sebagai dimensi kerahmatan. ${ }^{6}$

Dalam dimensi kerisalahan terdapat dua bentuk yakni irsyad dan tabligh. Irsyad penyebarluasan ajaran Islam secara sepesifik dikalangan tertentu, lebih berorientasi pemecahan masalah individu, memberi jalan keluar, dengan paket pesan yang sudah di rancang oleh pelaku dakwah. Sedangkan tabligh penyiaran ajaran Islam yang bersifat insidental, oral, massal seriemonial bahkan kolosal, yang berhubungan dengan peristiwa penting dalam kehidupan individu atau kolektif. Melalui sarana pemancaran atau transmisi dengan menggunakan media.Tabligh yang bermakna difusi adalah proses penyebaran ajaran Islam dengan bahasa lisan dan tulisan melalui bermacammacam media massa kepada orang banyak, baik secara serentak maupun tenggang waktu. ${ }^{7}$

Sedangkan dakwah dalam dimensi kerahmatan yakni upaya untuk menjabarkan nilai-nilai Islam normatif menjadi konsep-konsep kehidupan yang dapat dilaksanakan dalam kehidupan sehari-hari, yang dalam berwujudannya dalam bentuk tadbir dan tathwir.Yang dimaksud dengan tadhbir ialah sosialisasi ajaran Islam dengan mengoptimalkan lembaga organisasi dakwah formal maupun non formal, mencetak da'i profesional yang sesuai kebutuhan masyarakat. Sedangkan tathwir sosialisasi ajaran Islam kepada masyarakat mad'u untuk mempertinggi derajat kesalehan 
prilaku individu dan kelompok, sehingga dapat memecahkan masalah yang ada di masyarakat, tahtwir juga mencakup transformasi yakni proses mengubah ajaran Islam menjadi pengamalan berupa pemberdayaan (taghyir dan tamkin) sumber daya insani, lingkungan hidup dan ekonomi. ${ }^{8}$

Oleh karena dalam proses penyampaian dan pengamalan ajaran Islam dai memiliki peran strategis untuk menentukan keberhasilan tujuan dakwah yang diembannya. Sedangkan masyarakat juga mengharapkan figur ideal dan integritas yang sempurna pada diri dai, walaupun sebagai manusia dai tidak terlepas dari kesalahan dan kekurangan namun setidaknya seorang dai dituntut sekuat tenaga untuk terus memperbaiki diri agar dapat menjadi teladan bagi umat.

Selain memiliki ilmu pengetahuan yang luas serta ketrampilan profesional sebagai seorang dai integritas kepribadian dai juga akan menjadi hal penting yang menentukan keberhasilan dakwah seorang dai. Seperti pernyataan Hamka yang dikutip oleh Asmuni Syukir yang mengemukakan bahwa "Jayanya atau suksesnya suatu dakwah sangat tergantung pada pribadi pembawa dakwah itu sendiri, yang sekarang lebih populer kita sebut dai". ${ }^{9}$ Pernyataan tersebut menunjukkan bahwa keperibadian seorang dai akan menjadi salah satu foktor penting untuk menentukan keberhasilan dakwah.

Oleh karena itu, penting bagi seorang dai memiliki sikap dan integritas yang sesuai dengan tuntunan Islam, sehingga dai dituntut untuk memiliki keutuhan pribadi, yang menurut Sayid Quthub dalam buku A Ilyas Ismail bahwa intergritas menunjukkan pada sikap konsistensi dan persesuaian (muthabaqah), antara kata dan perbuatan dan antara keduanya dengan hati nurani dalam integritas itu terkandung makna kejujuran (as-sidq), dan konsistensi (al-istiqamah) dalam memperjuangkan kebenaran. ${ }^{10}$

Selanjutnya dai juga diharapkan oleh masyarakat menjadi figur ideal dalam masyarakat, sehingga dai dalam proses dakwah hendaklah memiliki citra dan image yang baik di dalam masyarakat. Seorang dai dikatakan kredibel harus memiliki kompetensi dibidangnya, integritas kepribadian, ketulusan jiwa dan memiliki status yang baik, karena dai harus menjadi saksi kebenaran, teladan umat, dan memiliki akhalak yang mencerminkan nilai-nilai Islam. ${ }^{11}$ Beberapa komponen tersebut merupakan faktor yang akan mendukung aktivitas dakwah seorang dai. Sehingga tujuan dakwah yang diharapkan akan lebih mudah untuk diwujudkan, karena 
dakwah tidak hanya menyampaikan ajaran Islam, tapi juga mengamalkan dalam bentuk perbuatan. ${ }^{12}$

Menurut M.Natsir dai bukan hanya sekedar menyampaikan ajaran Islam, tapi juga selain dalam bentuk lisan dakwah juga dalam bentuk amal. Konsep dakwah adalah amar ma'ruf nahi nunkar, yang di dalam nya mengandung tiga unsur utama yaitu amal perbuatan lisan, aktualisasi ajaran Islam dalam karya nyata, dan kepribadian terpuji sebagai sokogurunya Agar nilai-nilai Islam terwujud nyata dalam kehidupan keseharian masyarakat. 13

Sedangkan menurut Ali Badidha ada tiga sifat yang harus dimiliki oleh seorang dai yang sekaligus menjadi kunci urgen yang harus direalisasikan dalam dirinya. Dengan ketiga sifat tersebut dapat mendatangkan taufik Allah Swt, sehingga dai memiliki kemantapan jika bekerja sungguh-sungguh, jika membuat keputusan dia benar, dan jika berbicara membawa manfaat. Sifat-sifat tersebut adalah:

1. Keagungan iman kepada Allah Swt

2. Ikhlas karena Allah

3. Hubungan baik dengan Allah ${ }^{14}$ Selanjutkan menurut Hamka yang dikutip oleh Hafi Anshari tentang gambaran kepribadian yang harus diperhatikan oleh seorang dai, antara lain:

1. Hendaknya seorang dai membulatkan tekad dengan niat sematamata mengharapkan ridho Allah serta sadar terhadap apa yang disampaikannya.

2. Seorang dai harus teguh pendirian, jauh dari sifat riya', sumua'ah, ujub, dan tidak mudah putus asaserta jauh dari sifatsifat tercela lainnya.

3. Mengerti tentang pokok Al-Quran dan Sunnah dan juga memiliki pengetahuan tentang ilmu jiwa massa serta adat istiadat orang hendak didakwahi.

4. Dai harus memiliki sifat lemah lembut, tawadhu, pemaaf tapi disegani dan peduli terhadap ingkungan.

5. Dai harus menghindari menghindari pertentangan dan perdebatan.

6. Dai harus dapat menjadi teladan yang baik dan memiliki keutamaan dalam akhlak. 15

Penjelasan diatas menunjukkan bahwa sifat dan kepribadian seorang dai yang sering disebut juga integritas menjadi hal penting untuk mendukung proses kegiatan dakwah yang dapat mempermudah tercapainya tujuan dakwah. 


\section{Kesimpulan}

Tidak bisa dipungkiri bahwa dai memiliki peran sentral dalam kegiatan dakwah, karena diantara unsur yang lain dai memiliki posisi urgen yang akan menjadi motor penggerak dakwah. Oleh karena itu, selain mesti memiliki pengetahuan yang luas dan kompetensi profesional yang mumpuni, integraitas keperibadian yang tangguhdai akan menjadi faktor penting mempengaruhi kesuksesan suatu dakwah.

\section{Referensi}

\begin{tabular}{l}
\hline 1. Halim, "Paradigma \\
Pengembangan Masyarakat" dalam Moh Ali Aziz \\
dkk (ed), Dakwah Pemberdayaan Masyarakat \\
Paradigma Aksi dan Metodologi (Yogyakarta: \\
Pustaka Pesantren, 2009), 4-5.
\end{tabular}

2. Hafi Anshori, Pengalaman dan Pemahaman Dakwah, (Surabaya: Al Ikhlas, 1993), 11.

3. A Hasjmy, Dustur Dakwah Menurut AlQur'an, (Jakarta: Bintang, 1994). 1.

4. Fahullah Gulen, Thuruqul Irsyadi fi alfikri wa al-Hayaati,Terj. Ibnu Ibrahim, Dakwah Jalan Terbaik Dalam Berpikir dan Menyikapi Hidup, (Jakarta: PT Gramedia), 95

5. Departemen Agama RI, Al-Qur'an dan Terjemahnyaa, (Semarang: CV Toha Putra,1989), 670

6. Aep Kusnawan, "Arti dan Dimensi Dakwah", dalam Aep Kusnawan dkk, Dimensi Ilmu Dakwah Tinjauan Dakwah dari Aspek Ontologi, Epistemologi, Aksiologi, hingga Paradigma
Pengembangan Profesionalisme (Bandung: Widya Pedjadjaran, 2009), 17-25.

7. Aep Kusnawan dkk, Dimensi Ilmu

Dakwah Tinjauan Dakwah dari Aspek Ontologi,

Epistemologi, Aksiologi, hingga Paradigma

Pengembangan Profesionalisme, 18.

8. Aep Kusnawan, "Arti dan Dimensi

Dakwah", dalam Aep Kusnawan dkk, Dimensi Ilmu Dakwah Tinjauan Dakwah dari Aspek Ontologi, Epistemologi, Aksiologi, hingga Paradigma Pengembangan Profesionalisme (Bandung: Widya Pedjadjaran, 2009), 18-24

9. Asmuni Syukir, Dasar-Dasar Strategi

Dakwah Islam (Surabaya: Al-Ikhlas, 1981), 34.

10. A. Ilyas Ismail, Paradigma Dakwah Sayid Quthub, (Jakarta: Penamadani, 2006), h.320.

11. Alwi Shihab, Islam Inklusif (Bandung: Mizan, 1999), 254.

${ }^{12}$ Thohir Luth, M. Natsir Dakwah dan Pemikirannya (Jakarta: Gema Insani, 1999), 131.

13. Thohir Luth, M. Natsir Dakwah dan Pemikirannya. 132.

14. Ali Badhidha, Kunci Keberhasilan Pembentukkan Da'i, Waqfah Edisi 10, Vol 1 Tahun 1997,47

15. Hafi Anshori, Pengalaman dan Pemahaman Dakwah, (Surabaya: Al Ikhlas, 1993), 109. 